\title{
Three Key Issues on Contemporary Chinese Children Literature's Value Position
}

\author{
Manli Wang ${ }^{1, *}$ \\ ${ }^{1}$ Faculty of Humanities, Xi'an Peihua University, Peihua south road, Xi’an 710125, China \\ * Manli Wang
}

Keywords: children literature, narrative of suffering, aesthetic connotation, moral domestication, value of position

\begin{abstract}
The logical starting point and aesthetic core of children literature is childhood, it should point to the inner spiritual world of children, but the paradox is that adult writer who has already separated from the physical and emotional characteristics of children. Adult are dissolving children literature's original ecological characteristics when they expresses children's thoughts and emotions, many plots and themes of children literature deviate and misread the true emotional feelings of children. Children literature should base on beauty, or for the purpose of good? Should write misery or happiness? Should author target the commercial profit or the creative classic? These are dilemmas. This paper argues that children literature is same as all other aesthetic literary works, we should fuse beauty and good to the authenticity of the children's heart.
\end{abstract}

\section{Introduction}

Children read children literature, children books attract children readers with interest, color and moral education. Most of Chinese parents have no scientific guidance in choosing children books, they tend to choose books which advocate positive values because of sense of responsibility and thus evaluate a children's book is good or bad. Children literature is very important in constructing social discourse and values of children, especially to preschoolers, however, what is worth reflecting on is whether so many children literature in our country has truly succeeded in taking education responsibility for children? In social tide of commercialization, how the children literature maintain aesthetic and authenticity?

\section{Suffering narration or romantic imagination: the narrative position of children literature}

Children's psychology defines children between 3 and 12 years old according to their physical and emotional maturity. Compared with other groups, children has less social participation, a relatively young mind and their judgment is limited by age. Adult society should give what visualize of the future society to children? Sweet happiness or setbacks and hardships? This is directly related to the author's vision and purpose of construction of children's world .

Cao wenxuan's children novel Qingtong and Kuihua is believed contain a much clearer aesthetic intention to mental writing of childhood, this is related to Cao wenxuan's understanding of children literature,he thinks that children literature should include another pleasure of tragedy associated with suffering, it can enrich the life experience of childhood, deepen the understanding of the true life. In the mid 1990s, the short children novels that Cao began to write was his original thinking about children literature,it contains most of the literary propositions of his late children novels. In that period, Cao wrote children literature in the same way as other general literary types, and did not highlight the particularity of the former.

The most representative of the children literature is the fairy tale. The reading attitude of the fairy tale is relaxed, readers know that the protagonist of the fairy tale will ultimately gain happiness no matter how many hardships and sufferings they experiences. Children's minds are mostly simple, and they equate the sweetness and beauty of the work to real world, we adults know 
that the truth of the world is sometimes opposite. We do not deny the sweetness of children literature, but we should reduce some sweetness from children literature when shape the child's future personality and the resilience to suffering. What should we treat the author who write ugly and suffering of the world? Suffering refers to the difficult survival of the child hero, or the painful process of mental suffering? Some authors exaggerate the suffering and the happy ending that the result divorced from the reality of the world. Suffering is an aesthetic category rather than a social encounter, suffering itself should not be a romanticized object, what really matters is that the individual, including his childhood, feels the power of will to life and spirit, it doesn't come from the ups and downs of life, but from the truest and most simple life details.

The children literature author imagine children's world too pure and idealistic, it tends to simplify the child world to black or white, ugly or beautiful, right or wrong, which lack of real life's richness and fullness. In fact, the children have the same experience like adult, but a lot of children literature ignore this fact because they worry about that is no longer children literature if write the complex of life. That's a big mistake. Children literature should picture the middle area, this is very important to change the phenomenon that most children literature has sufficient simplicity but insufficient depth .

\section{Moral domestication or aesthetic infiltration: the value position of children literature}

Children learn and imitate discourse from children literature to communicate with others, express self-awareness and feelings and establish a preliminary social and cultural identity. The writer of children literature is mostly adult, so what children read and acquire is the ethical values of adults, or at least the adult wants to convey to children. The moral domestication of children literature is done in the process of children's unconscious, which is the moral abduction of the adult world. Adults believe in children's mind is not strong that children can't accept the fuzzy judgment, otherwise it will cause the disorder of values, thus adults give children's moral discipline with simple either this or that. Children regard parents and teachers as moral authority and consciously to use this discourse weapons as a preliminary moral judgment to judge right and wrong, but this kind of judgment is relatively simple. From an elder children's view, most of fairy tales are lies, pure beauty in the book become an obstacle when they deal with social problems, thus they feel a sense of powerlessness. We certainly cannot deny values of children literature to young children, but whether the values of the adult world are suitable for children? To what extent is it applicable to children's world? It needs a further discussion. The authors of children literature are mostly adults, and they can only imagine the children world by recalling, associations and imagination.

Traditional children literature convey a potential value that instruct boys and girls grow into their social role by sowing the seeds of adult values. Children literature is the social choice and selection for children to read, after the message is generally accepted and approved by the mainstream values, the values are so subtly that very few people to reflect on. Children are less likely to be because of mental immature.

Children literature should build theme, language and communicate skills on shaping of aesthetic personality in children, and the values of identity should serve the aesthetic education of personality. Children literature is a means of moral education, but it also should be an art and a literature. In 1988, Cao wenxuan said in an interview that he look forward to poetic feature and children's perspective can help him achieve his desired goals and satisfy his aesthetic interest. However, for a long time, the first concerned factor of children literature in China is to educate children. At present, some children literature has written and published with specified theme, which greatly restricted the aesthetic expression and artistic space of children literature. Because of the particularity of children's body and mind, children literature should be interesting and lovely, should convey beautiful feelings to children in order to let children understand social moral system. Good and beautiful is a cliche, but it is still very important to structure the aesthetic value and moral value of Chinese contemporary children literature. 


\section{Seek wealth or create classic: the creative position of children literature}

What is the creative position of children literature? Write a business bestseller, or a classic for children? Chinese children literature is affected by multiculture of post-modern society and electronic technology, the type of children books become varied. But some children literature writers and publishers seek commercial profits, pursue blindly and speculate, deviated from something inherent of children literature.

Picture books are the first choice for parents who have young children because picture books are colorful and attractive to children. However, pictures and words can give readers very different feeling. Text reading, even if silent reading, is also a process of constructing self-consciousness and independent personality, but reading pictures will weaken children's reading ability and aesthetic consciousness, especially for children who can have a preliminary reading. Many creators cater to consumers' pleasure and draw young readers'attention with pictures even they know many pictures are useless to deep reading.

Foucault mentioned many famous cases during the university lecture in the 1970s, which showed the significance of children's mental health and adult normal personality in different degrees. Children are sensitive and vulnerable, and if they suffer from psychological stress or injury, it is very likely that they will develop into a mental illness or become criminal behavior in adulthood. Now many children are emotionally cold and lack compassion even to the same kind, they bully other children to prove their power, it is an extremely deplorable value. There is no denying that at present a lot of children imitate words and deeds from potboiler which full of violence and decadence, it is associated with the authors who lack of sense of responsibility.

The writing of children literature is a kind of humanistic writing, which should respect the rules of children's emotional and psychological development, authors should close to the state of children's life infinitely and protect the children's heart with the words of aesthetics. The pursuit of artistic children literature may not conform to the operational requirements in commercial children's book market, but the poetic pursuit of literature can make it stand the test of history. Children literature is extremely important to shape the future of children, contemporary children's feeling, emotion and personality are almost formed under the influence of children literature, so we need a group of conscientious and aspiring authors. Excellent children literature works not only reflect the real childhood in a certain way, but also a philosophical and aesthetic improvement of the real childhood. The attention and discussion about the aesthetic problems of the original children literature should be a central position of contemporary children literature.

\section{Conclusion}

Children literature is a kind of literature, it is the product of social and cultural construction which inherit ethical value and morality consciously or unconsciously, therefore it is impossible to divest ethical stance from the children literature. Even Cao wenxuan, who pursues more literariness in children literature, has also said that children literature writer is the shaper of future national character. Ideology and aesthetics should be harmoniously integrated into literature, children literature will lost its legitimacy and existence value if it sermonize the children only.

\section{References}

[1] Weiping Fang.The Thinking of Childhood Aesthetics in Contemporary Original Children's Literature.Contemporary writers review, 2015.03.

[2] Weiping Fang,Xia Zhao.The Childhood Aesthetics and Reflection of Contemporary Children's Novels about Yang hongying Phenomenon.Contemporary writers review,2012.05.

[3] Shuying Qian. Children's Perspective and Aesthetic Imagination: Critique of Cao wenxuan's Short Children's Novels. Contemporary writers review, 2016.03.

[4] Hui Chen. The Theme and Expression of Children's Picture Books.Journal of Shenzhen 
university (Humanities and Social Sciences Edition), 2009.05.

[5] Foucault. Discipline and Punishment. Shanghai: Shanghai sanlian bookstore,2007.

[6] Mei-ni Zhang,Yang Chao.Introduction to Early Childhood Literature. Chongqing: Chongqing press, 1996.

[7] Xuemen Zhang. Handout on Children's Literature (Children's Normal Books).Beijing: xiangshan college,1930.

[8] RenluWang.Research on Children's Books.Shanghai: China book bureau,1933.

[9] Enli Chen. The Moral Anxiety and Machine Totem: Culture Criticism of Zheng yuanjie's Bestselling Fairy Tale.Guizhou social science, 2011.06.

[10] Xudong Tan.The Value Pursuit of Literature Children's Book. China publishing,2007.06. 